\title{
The Reduction of Methaemoglobin by Ascorbic Acid
}

\author{
By Q. H. GIBSON, Department of Biochemistry, The Queen's University, Belfast
}

(Received 2 October 1943)

In idiopathic methaemoglobinaemia, of which we have investigated some cases, the occurrence of an atypical form of methaemoglobin abnormally resistant to reduction has been postulated by Lian, Frumusan \& Sassier [1939] as an aetiological factor. It thus became of interest to examine the evidence which has been put forward by Vestling [1942] against the unitary view of methaemoglobin. This author found that methaemoglobin made from haemoglobin by the action of nitrite was much less readily reduced by ascorbic acid than methaemoglobin formed by the action of ferricyanide, and suggested that these two spectroscopically similar products [Austin \& Drabkin, 1935] differed chemically. The reaction is also of interest because it has been applied clinically by Deeny, Murdock \& Rogan [1943] in the treatment of idiopathic methaemoglobinaemia.

The experiments reported here indicate that there is no chemical difference between nitrite- and ferricyanide-prepared methaemoglobin, so far as reduction by ascorbic acid is concerned, and that the differences observed by Vestling are due to the presence of ferrocyanide.

\section{METHODS}

Crystalline horse haemoglobin was prepared following Taylor \& Hastings [1939], and was preserved in the icechest in contact with toluene. Methaemoglobin (MHb) was determined by the method of Evelyn.\& Malloy [1938], using a Hilger Spekker absorptiometer with filter no. 1 (red), of set H. 455, transmitting light of wave-lengths greater than $620 \mathrm{~m} \mu$. A calibration curve was prepared by using known amounts of MHb prepared from haemoglobin solutions which had been standardized with the Van SlykeNeill manometric apparatus.

Determinations of total pigment were made by the method of Clegg \& King [1942], again using the Spekker absorptiometer with filter no. 5 (green), of set H. 455 (maximal transmission between 500 and $580 \mathrm{~m} \mu$ ), and a calibration curve prepared with the aid of the Van Slyke apparatus.

In order to follow the course of the reaction between $\mathrm{MHb}$ and ascorbic acid; haemoglobin solutions having a concentration of about $10 \mathrm{~g} . / 100 \mathrm{ml}$. were prepared with $\mathrm{M} / 20$ phosphate buffer, $\mathrm{pH} \mathbf{7 \cdot 4}$, and partially converted to $\mathrm{MHb}$ by the addition of either one equivalent of $\mathrm{NaNO}_{2}$ or of $\mathrm{K}_{3} \mathrm{Fe}(\mathrm{CN})_{6}$. The resulting solution $(2 \mathrm{ml}$.) was placed in the main chambers of a series of Barcroft manometric flasks of the usual type. The required amount of $l$-ascorbic acid (B.D.H. synthetic), dissolved in M/3 phosphate buffer, pH $7 \cdot 4$ was contained in Keilin tubes. The manometers were filled with a mixture of $20 \%$ CO (prepared from formic acid), and $80 \% \mathrm{~N}_{2}$. After equilibration by $15 \mathrm{~min}$. shaking in the water-bath, the ascorbic acid was added from the Keilin tubes and the reaction followed by the uptake of $\mathrm{CO}$ by the haemoglobin formed from $\mathrm{MHb}$. At the end of an experiment, the final concentration of $\mathrm{MHb}$ in each flask was estimated with the absorptiometer.

A few experiments were carried out in the presence of $\mathrm{N}_{2}$ only; here a modified Thunberg tube was used with a tap attached to the bottom, by means of which samples of solution could be withdrawn during the course of an experiment. The $\mathrm{MHb}$ solution was placed in the main tube, the ascorbic acid in the side arm, and the vessel repeatedly evacuated and refilled with $\mathrm{N}_{2}$. The solutions were then mixed and portions removed at intervals for determination of $\mathrm{MHb}$.

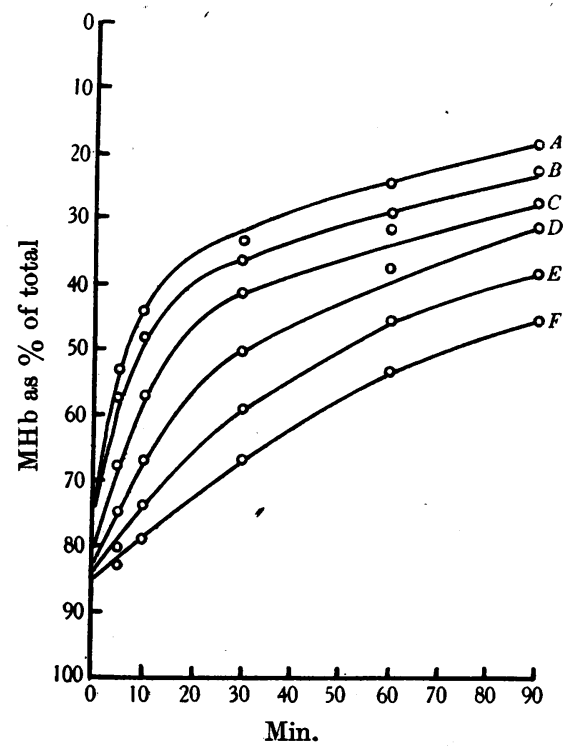

Fig. 1. The effect of ferrocyanide on the reduction of nitrite-methaemoglobin by ascorbic acid. In all manometers, $6 \cdot 6 \mu \mathrm{mol}$. methaemoglobin and $6 \cdot 6 \mu \mathrm{mol}$. ascorbic acid. $\mathrm{K}_{4} \mathrm{Fe}(\mathrm{CN})_{6}: A, 13 \cdot 2 \mu \mathrm{mol}$; $B, 6 \cdot 6 \mu \mathrm{mol}$; $C, 3 \cdot 3 \mu \mathrm{mol}$.; $D, 1.7 \mu$ mol.; $E, 0.8 \mu$ mol.; $F$, nil. Temp. $=28^{\circ}$. Total vol. in each, $2 \cdot 2 \mathrm{ml}$.

\section{RESULTS}

The effect of ferrocyanide on the rate of reduction of nitrite-methaemoglobin. The effect of the addition of varying amounts of $\mathrm{K}_{4} \mathrm{Fe}(\mathrm{CN})_{6}$ on the reaction between nitrite-methaemoglobin (nitrite-MHb) and ascorbic acid is shown in Fig. 1. With the amount 
of $\mathrm{CO}$ absorbed in the first $5 \mathrm{~min}$. as a measure of the velocity of the reaction, it was found that the acceleration produced was directly proportional to the amount of ferrocyanide added until the level of one equivalent was reached; beyond this point the relation does not hold, in part because a $5 \mathrm{~min}$. period is too long to give a true measure of the initial velocity of the reaction when this is high. It will be noticed that in Fig. 1 the amounts of MHb present initially are different. When ferrocyanide acts upon a solution containing $\mathrm{MHb}$, the formation of haemoglobin and ferricyanide takes place until equilibrium is reached. Since the ferrocyanide was added to the MHb solutions before the beginning of the experiment, this reaction was largely completed during the equilibration period and led to a diminished initial $\mathrm{MHb}$ concentration in the manometers containing large amounts of ferrocyanide.

Comparison between ferricyanide-methaemoglobin and nitrite-methaemoglobin. The effect of the addition of ferrocyanide on the rate of reduction of nitrite-MHb made it likely that the observed difference between it and ferricyanide-methaemoglobin (ferricyanide-MHb) might be due to the

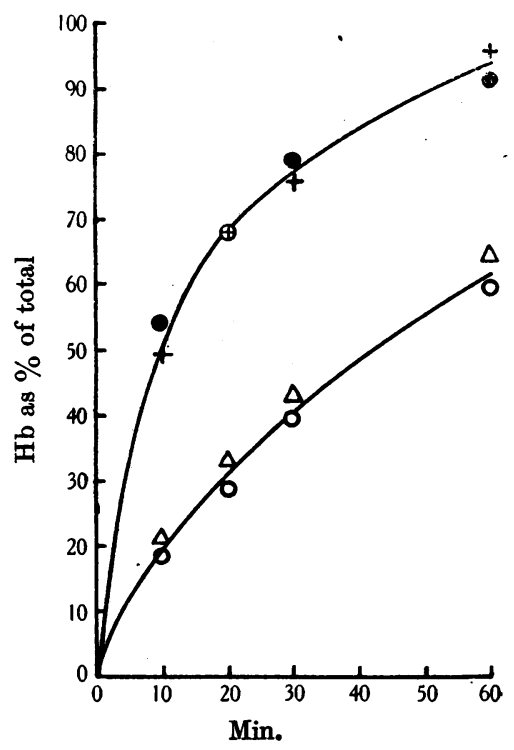

Fig. 2. Comparison between nitrite-methaemoglobin and ferricyanide-methaemoglobin. In each manometer 6.2 $\mu \mathrm{mol}$. methaemoglobin and 6.2 $\mu \mathrm{mol}$. ascorbic acid. Total volume $2 \cdot 2 \mathrm{ml}$. Temp. $=37^{\circ}$. $\bigcirc$ Dialyzed ferricyanide-MHb. $\triangle$ Nitrite-MHb. + Dialyzed ferricyanide-MHb $+6 \cdot 2 \mu \mathrm{mol} . \quad \mathrm{K}_{4} \mathrm{Fe}(\mathrm{CN})_{6}$. $\quad$-Nitrite-MHb $+6 \cdot 2 \mu \mathrm{mol}$. $\mathrm{K}_{4} \mathrm{Fe}(\mathrm{CN})_{6}$.

presence of ferrocyanide formed during the preparation of the latter. To test this point, a concentrated solution of ferricyanide-MHb was dialyzed in a collodion sac against tap water for $24 \mathrm{hr}$. The resulting solution had a $\mathrm{MHb}$ concentration of $5.2 \mathrm{~g} . / 100 \mathrm{ml}$; the rate of reduction by two equivalents of ascorbic acid with and without one equivalent of potassium ferrocyanide was compared with the rate of reduction of a nitrite- $\mathrm{MHb}$ solution of equal concentration. The results are shown in Fig. 2 and support the view that there is no essential difference between the two types of $\mathrm{MHb}$.

The mechanism of the catalytic action of ferrocyanide on the reduction of methaemoglobin. The most obvious suggestion is that the iron in the ferrocyanide acts as a catalyst by being alternately oxidized and reduced according to the following reactions :

$$
\begin{aligned}
\mathrm{Fe}^{+++}(\mathrm{MHb})+ & \text { ferrocyanide } \rightarrow \mathrm{Fe}^{++}(\mathrm{Hb})+\text { ferrioyanide. } \\
\text { Ferricyanide }+ & \text { ascorbic acid } \\
\rightarrow & \text { ferrocyanide }+ \text { dehydroascorbic acid. }
\end{aligned}
$$

In order that the first reaction may proceed from left to right, it is a necessary condition that the ratio ferri-/ferro-cyanide be such that the e.m.f. of the system $\left(E_{0}^{\prime}=+406 \mathrm{mV}\right.$. [Michaelis, 1933]), shall be less positive than that of the system $\mathrm{MHb} / \mathrm{Hb}$ $\left(E_{0}^{\prime}=+140 \mathrm{mV}\right.$. at $\mathrm{pH} 7$ [Taylor \& Hastings, 1939]). If equimolecular amounts of $\mathrm{MHb}$ and $\mathrm{Hb}$ were present, fulfilment of this condition would require that the ratio ferri-/ferro-cyanide should be less than $1: 27,000$. This consideration, however, does not rule out the possibility of this reaction in the experiments just quoted, because these were carried out in the presence of $\mathrm{CO}$, which, by combining with free $\mathrm{Hb}$, so alters the value of the quotient $\mathrm{MHb} / \mathrm{Hb}$ that the effective $E_{0}^{\prime}$ of the system, as calculated from the equilibrium reached in the presence of ferrocyanide, becomes about $+380 \mathrm{mV}$. It would be expected that in the absence of a gas with which haemoglobin combines, the catalytic effect of ferrocyanide would be much reduced or would disappear. Repetition of the experiments shown in Fig. 2 in an atmosphere of $\mathrm{N}_{2}$ led to results which were, within experimental error, precisely similar to those obtained in the presence of $\mathrm{CO}$, suggesting, therefore, that ferrocyanide, as such, does not act by being alternately oxidized and reduced. The true nature of the catalysis remains obscure.

Catalysis of the reduction of methaemoglobin by metals. The existence of ferrocyanide catalysis suggested that other substances might share this property and it has, in fact, been found that copper and iron both exert a considerable effect on the rate of reduction. The effect of $\mathrm{FeSO}_{4} \cdot\left(\mathrm{NH}_{4}\right)_{2} \mathrm{SO}_{4} \cdot 6 \mathrm{H}_{2} \mathrm{O}$ and $\mathrm{CuSO}_{4}$ is shown in Table 1. Some part of the 'normal' reaction between $\mathrm{MHb}$ and ascorbic acid is probably due to traces of metals present in the solutions, for it was found that saturation with 8-hydroxyquinoline (combining with copper) and $\alpha \alpha^{\prime}$. dipyridyl (combining with ferrous iron) reduced the rate of reduction by some 50 and $20 \%$ respectively. 
Table 1. Catalysis of the reduction of methaemoglobin by $\mathrm{Fe}$ and $\mathrm{Cu}$

\begin{tabular}{|c|c|c|}
\hline & $\begin{array}{c}\text { Metal catalyst } \\
\text { ( } \mu \text { g. } / \mathrm{ml} .) \\
\text { None }\end{array}$ & $\begin{array}{c}\text { Methaemoglobin } \\
\text { reduced in } \mathbf{3 0} \text { min. } \\
(\mu \mathrm{mol} .) \\
\mathbf{3 \cdot 4}\end{array}$ \\
\hline $\mathrm{Fe}$ & $\begin{array}{l}25 \\
50\end{array}$ & $\begin{array}{l}5 \cdot 1 \\
5 \cdot 4\end{array}$ \\
\hline $\mathrm{Cu}$ & $\begin{array}{l}25 \\
50\end{array}$ & $\begin{array}{l}4 \cdot 7 \\
5 \cdot 1\end{array}$ \\
\hline
\end{tabular}

Methaemoglobin $(12.0 \mu \mathrm{mol}$. in $2 \mathrm{ml}$. $)+$ ascorbic acid (two equiv.). Vol. $=2 \cdot 2 \mathrm{ml}$; temp. $=28^{\circ}$. The data given are the means of duplicate determinations.

The mechanism of the reaction between nitritemethaemoglobin and ascorbic acid. The, reaction between $\mathrm{MHb}$ and ascorbic acid appears to be satisfactorily described by the equation for a bimoleqular reaction, as shown by the reasonably constant values of $k$ (velocity constant), obtained by substitution in the bimolecular formula. Table 2

Table 2. Velocity constant for the reduction of methaemoglobin by ascorbic acid

$\begin{array}{ccc}\begin{array}{c}\text { Time } \\ (\text { hr. })\end{array} & \begin{array}{c}\text { CO uptake } \\ (\mu \mathrm{l} .)\end{array} & k \\ 0.17 & 14 & 1 \cdot 43 \\ 0.50 & 34 & 1 \cdot 33 \\ 1.0 & 50 & 1 \cdot 15 \\ 1.5 & 63 & 1 \cdot 13 \\ 2.0 & 73 & 1 \cdot 15\end{array}$

Methaemoglobin $(6 \cdot 0 \mu \mathrm{mol}$. in $2 \mathrm{ml}$.) + ascorbic acid (one equiv.). Vol. $=2 \cdot 2 \mathrm{ml}$.; temp. $=37^{\circ}$.

shows the analysis of one experiment. Determination of the order of the reaction by observation of the time required to reach $50 \%$ reduction, starting with equivalent quantities of reactants at varying concentrations, also supported this conclusion (Table 3).

Table 3. Inverse proportionality between concentration of reactants and time required to reach $50 \%$ reduction of methaemoglobin

\begin{tabular}{|c|c|c|c|}
\hline \multirow{2}{*}{$\begin{array}{c}\text { Initial } \\
{[\mathrm{MHb}]} \\
\text { (g./100 ml.) }\end{array}$} & \multicolumn{2}{|c|}{$\begin{array}{c}\text { Time of } 50 \% \text { reduction } \\
(t, \text { min. })\end{array}$} & \multirow{2}{*}{$\begin{array}{l}\text { Product: } \\
\text { [MHb] } \times t\end{array}$} \\
\hline & Individual results & Mean & \\
\hline $\begin{array}{r}10 \cdot 0 \\
8 \cdot 4 \\
5 \cdot 0 \\
4 \cdot 2\end{array}$ & 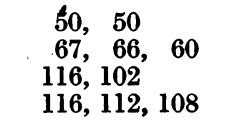 & $\begin{array}{r}53 \\
63 \\
109 \\
112\end{array}$ & $\begin{array}{l}\mathbf{5 3 0} \\
\mathbf{5 2 8} \\
\mathbf{5 4 5} \\
\mathbf{4 7 0}\end{array}$ \\
\hline & & & Av. $\overline{518}$ \\
\hline
\end{tabular}

The effect of ascorbic acid concentration on the rate of reduction of methaemoglobin. The initial rate of reaction with constant $\mathrm{MHb}$ concentration should be proportional to the ascorbic acid concentration. An attempt to verify this relation was made by measuring the gas uptake during the first $10 \mathrm{~min}$. of the reaction, with varied amounts of ascorbic acid in the presence of two equivalents of glutathione, which, while itself reacting only slowly with $\mathrm{MHb}$, maintained the ascorbic acid in the reduced form and enabled measurable gas uptakes to be obtained with the smaller concentrations of ascorbic acid. The results are shown in Table 4. The apparent

Table 4. Effects of ascorbit acid concentration and 8-hydroxyquinoline on reduction of methaemoglobin

$\mu \mathrm{l}$. CO absorbed in $10 \mathrm{~min}$.

\begin{tabular}{|c|c|c|c|c|c|}
\hline \multirow{2}{*}{$\begin{array}{l}\text { Ascorbic } \\
\text { acid } \\
(\mu \mathrm{mol} .)\end{array}$} & \multicolumn{2}{|c|}{$\begin{array}{l}\text { 8-Hydroxy- } \\
\text { quinoline } \\
\text { absent }\end{array}$} & \multicolumn{2}{|c|}{$\begin{array}{l}\text { 8-Hydroxy- } \\
\text { quinoline } \\
\text { present }\end{array}$} & \multirow{2}{*}{$\begin{array}{c}\text { Inhibi- } \\
\text { tion } \\
(\%)\end{array}$} \\
\hline & Gross & Net & Gross & Net & \\
\hline- & 11 & $\bar{x}$ & 10 & - & - \\
\hline 0.8 & 31 & 20 & 16 & 6 & 70 \\
\hline 1.5 & 43 & 32 & 20 & 10 & 69 \\
\hline 3 & 54 & 43 & 25 & 15 & 65 \\
\hline 6 & 73 & 62 & 36 & 26 & 58 \\
\hline 12 & 89 & 78 & 45 & 35 & 55 \\
\hline
\end{tabular}

Methaemoglobin $(12 \mu \mathrm{mol})+$. glutathione $(24 \mu \mathrm{mol}$.$) .$ Vol. $=2 \cdot 2 \mathrm{ml}$.; temp. $=37^{\circ}$.

velocity with small concentrations of ascorbic acid was much in excess of expectation, while the inhibition produced by saturation with 8-hydroxyquinoline was more marked in the case of low concentrations of ascorbic acid, suggesting that the reaction usually observed is made up of two components, the one a direct reaction between ascorbic acid and $\mathrm{MHb}$, the other a reaction catalyzed by traces of metals in solution, the latter being little affected by increase of the ascorbic acid concentration beyond a low limiting value.

\section{DISCUSSION}

While similar behaviour towards ascorbic acid does not necessarily indicate that nitrite-MHb and ferricyanide-MHb are identical, the present results remove the experimental basis for the contrary view.

It may be remarked that Vestling [1942] found an equilibrium was reached between ferricyanide$\mathrm{MHb}$ and two equivalents of ascorbic acid when $83-95 \%$ of the MHb had been reduced. In this series of experiments, it has been found that when sufficient time is allowed (24 $\mathrm{hr}$. at room temperature) reduction proceeds so far that the residual MHb does not amount to more than $1-2 \%$ of the total pigment present. In view of the large difference between the potentials of the ascorbic acid and $\mathrm{MHb} / \mathrm{Hb}$ systems in the presence of a gas combining with $\mathrm{Hb}$, and the instability of dehydroascorbic acid, it would appear that the concept of an equilibrium must be largely illusory, and that Vestling's results may best be explained by the 
occurrence of secondary oxidative changes (for his experiments were not carried out under anaerobic conditions), and by the probability that insufficient time was allowed for the reaction to go nearly to completion.

Extrapolation from the results obtained in vitro suggests that the rate of reduction of methaemoglobin, which could be expected with the concentrations of ascorbic acid likely to occur in vivo, would be small-as compared with the rate of reduction of the pigment brought about by the enzymic mechanism of normal erythrocytes [Cox \& Wendel, 1942]. The clinical use of ascorbic acid in the treatment of methaemoglobinaemia would thus appear to be limited to cases in which the normal enzymic mechanism for the removal of methaemoglobin is absent or has become suppressed.

\section{SUMMARY}

1. It has been confirmed that ferricyanidemethaemoglobin, as ordinarily prepared, is reduced more rapidly by ascorbic acid than is nitritemethaemoglobin.

2. This difference is due to the catalytic effect of ferrocyanide on the reduction of methaemoglobin. There is thus no basis for the supposition that this effect indicates a chemical difference between the two forms of methaemoglobin.

3. Iron and copper salts produce similar catalytic effects.

4. The reaction between ascorbic acid and methaemoglobin is described by the equation for a bimolecular reaction.

The author wishes to thank Prof. D. C. Harrison for much helpful criticism and advice.

\title{
REFERENCES
}

Austin, J. H. \& Drabkin, D. L. [1935]. J. biol. Chem. $112,67$.

Clegg, J. W. \& King, E. J. [1942]. Brit. med. J. 2, 329.

Cox, W. W. \& Wendel, W. B. [1942]. J. biol. Chem. 143, 331.

Deeny, J., Murdock, E. T. \& Rogan, J. J. [1943]. Brit. med. J. 1, 721 .
Evelyn, K. A. \& Malloy, H. T. [1938]. J. biol. Chem. $128,655$.

Lian, C., Frumusan, P. \& Sassier, M. [1939]. Bull. Soc. Méd. Hôp. Paris, 55, 1194.

Michaelis, L. [1933]. Oxydations-Reductions-Potentiale, 2nd ed., p. 61. Berlin: Springer.

Taylor,J.F.\& Hastings, A. B. [1939]. J.biol. Chem. 131, 649. Vestling, C. S. [1942]. J. biol. Chem. 143, 439.

\section{The Assimilation of Glucose and Galactose in the Liver}

\author{
By H. W. KOSTERLITZ aNd CAROLINE M. RITCHIE (Carnegie Research Scholar), \\ Physiology Department, Marischal College, Aberdeen
}

(Received 20 September 1943)

In this paper an attempt is made to examine the intermediary metabolism of glucose and galactose in the liver of the intact animal. In vitro experiments [Cori, Cori \& Schmidt, 1939; Ostern, Herbert $\&$ Holmes, 1939] have proved that glucose-1-phosphate and hexose-6-phosphate are intermediaries in the glucose and glycogen metabolism of the liver. Both galactose-1-phosphate and glucose-1-phosphate have been found in the livers of rabbits assimilating galactose [Kosterlitz, 1937; 1943a]. In the present investigation, in addition to the phosphoric esters, glucose, galactose, and glycogen were estimated in the livers of rats at varying intervals after ingestion of glucose or galactose.

\section{METHODS}

General. Male rats from the Rowett Research Institute were kept on the stock diet. Prior to the experiment they were fasted for $24 \mathrm{hr}$., and then fed by stamach tube with either $1.5 \mathrm{ml}$. of $60 \%(\mathrm{w} / \mathrm{v})$ galactose solution $/ 100 \mathrm{~g}$. body weight, or with $1.5 \mathrm{ml}$. of $55 \%(\mathrm{w} / \mathrm{v})$ glucose solution. After 30, 60, 90 or $120 \mathrm{~min}$. the rats were killed by stunning and the livers excised. After about $0.5 \mathrm{~g}$. liver had been placed in $30 \% \mathrm{KOH}$ for glycogen estimation, the remainder was frozen in liquid $\mathrm{O}_{2}$; samples of the frozen liver were used for the various estimations.

Estimation of glucose and galactose. The $\mathrm{HgSO}_{4}-\mathrm{BaCO}_{3}$ method of West, Scharles \& Peterson [1929] was used for the preparation of protein-free filtrates. Absence of traces of $\mathrm{Ba}^{++}$and $\mathrm{Hg}^{++}$was ensured by the addition of two drops of saturated solution of $\mathrm{K}_{2} \mathrm{SO}_{4}$ and of a small quantity of $\mathrm{Zn}$ powder. Glucose and galactose were estimated in the/ filtrate by the fermentation method previously described [Kosterlitz, 1937].

Estimation of glycogen. Our micro-adaptation of Pflüger's method was used [Kosterlitz, 1933], with $30 \% \mathrm{KOH}$ as digestion fluid.

Estimation of reducing phosphoric esters, glucose-1-phosphate and galactose-1-phosphate. This method has previously been described [Kosterlitz \& Ritchie, 1943]. The results are given under the following headings: (1) 'Initial reduction', 